\title{
Effect of microbial transglutaminase crosslinking on the functional properties of yak caseins: a comparison with cow caseins
}

\author{
Min Yang ${ }^{1,2} \cdot$ Ying Shi ${ }^{2,3} \cdot$ Qi Liang ${ }^{2,3}$
}

Received: 19 February 2015 /Revised: 11 May 2015 / Accepted: 18 May 2015 /

Published online: 17 June 2015

(C) INRA and Springer-Verlag France 2015

\begin{abstract}
Microbial transglutaminase (mTGase) crosslinking is a useful method for significantly improving the physical functionality of proteins. This study focused on the effect of mTGase modification on the functional properties of yak and cow caseins, including solubility, emulsifying property, water and oil absorption capacity, foaming property, and stability in the presence of $\mathrm{Na}^{+}, \mathrm{Ca}^{2+}$, and $\mathrm{Mg}^{2+}$. The results showed that the crosslinking degree of yak and cow caseins differed at the same mTGase concentration, but the change in functional properties of cow and yak caseins was similar. After mTGase crosslinking, the solubility of caseins decreased, while the emulsifying properties increased because of casein polymerization. MTGase crosslinking was very effective in improving water and oil absorption properties, stability in the presence of $\mathrm{Na}^{+}, \mathrm{Ca}^{2+}$, and $\mathrm{Mg}^{2+}$, and foaming activity, but did not affect the foam stability of cow acid caseins (caseins content of $94.22 \%, w / w$ ) and yak acid caseins (caseins content of $94.28 \%, w / w$ ). The results could be used as a reference for selecting the proper modification method to improve the predetermined functional properties of caseins according to industrial processing requirements.
\end{abstract}

Keywords Microbial transglutaminases $\cdot$ Crosslinking $\cdot$ Yak caseins · Cow caseins Functional properties

\section{Min Yang}

yangmin@gsau.edu.cn

1 College of Science, Gansu Agricultural University, Lanzhou, China

2 Functional Dairy Product Engineering Lab of Gansu Province, Lanzhou, China

3 College of Food Science and Engineering, Gansu Agricultural University, Lanzhou, China 


\section{Introduction}

Good functional properties of proteins are essential characteristics for the production of a wide range of food products. Caseins are the main protein in milk and are largely used as ingredients in the food industry. To expand the application of caseins, transglutaminases (TGase) crosslinking has been used to enhance their stability and functional properties. It was found that the nitrogen solubility of crosslinked sodium caseinate was improved at $\mathrm{pH} 2.0,3.0$, and 5.0, and the emulsifying activity index and stability were improved at pH 5.0 and 10.0 (Flanagan et al. 2003). Lorenzen (2000) reported that the stability and viscosity of emulsions prepared with crosslinked sodium caseinate increased, but the foam volume and stability of crosslinked sodium caseinate decreased compared to non-crosslinked sodium caseinate. The strength and kinetics of casein gelation, sensitivity to heat treatment, and syneresis behavior changed after TGase treatment (Vasbinder et al. 2003). It was also found that the casein gels produced by TGase crosslinking had higher viscoelastic moduli and gel stiffness, they formed quickly, and exhibited no syneresis even after a long storage time (Ardelean et al. 2013; Schorsch et al. 2000a, b). Some researches have shown that TGase treatment improved the stability of casein micelles (Flanagan et al. 2003; Huppertz and de Kruif 2007; Partschefeld et al. 2007; Smiddy et al. 2006).

In recent years, there has been a concerted effort toward developing yak caseins as high-quality ingredients in the food industry. This is because the composition of yak milk differs from cow milk. It was showed that yak milk has a high concentration of total proteins $\left(46.2-58.4\right.$ g. $\left.\mathrm{L}^{-1}\right)$ and total caseins $\left(40.2\right.$ g. $\left.\mathrm{L}^{-1}\right)(\mathrm{Li}$ et al. 2010). The high content of $\beta$-casein (more than $45 \%$ ) and consequently the lower proportion of $\alpha$ s-casein (about $40 \%$ ) together with the high content of $\mathrm{K}$-casein $(15 \%)$ in yak milk make it with a good proportion of individual caseins, which is similar to the proportion found in human milk and more favorable for infant nutrition (Li et al. 2010). It also found the high content of minerals and micellar size of yak milk (Wang et al. 2013; Yang et al. 2014b). To develop yak caseins for use as good ingredients in the food industry, their physicochemical and functional properties must be improved.

Some researchers have found that a TGase-catalyzed reaction is influenced by various parameters, such as the conformation of proteins, the chemical reagents, the ionic strength, and so on, while the neighboring amino acids of lysine residues could influence reactivity of lysine residues toward TGase crosslinking (Jaros et al. 2006). The amino acid sequence, the content of minerals, the proportion of yak casein monomers, and the size of yak casein micelles are different from those of cow caseins. Therefore, the effect of microbial transglutaminase (mTGase) modification on the functional properties of yak caseins should differ from cow caseins.

The objective of this study was to assess the effect of mTGase crosslinking on the functional properties of yak caseins, which were compared to cow caseins. The finding could provide basic data on the functional properties of mTGase-crosslinked yak caseins, and the results can be used as a reference for selecting the proper modification method to improve the predetermined functional properties of yak caseins according to industrial processing requirements. 


\section{Materials and methods}

\subsection{Materials}

Yak and cow acid caseins, provided by Gansu hualing Biotechnology company, had a caseins content of 94.28 and $94.22 \%(w / w)$, respectively. MTGase $(99 \%$ maltodextrin,

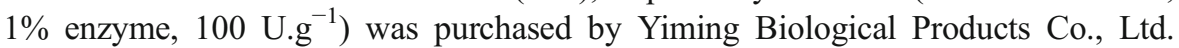
(Jiangsu, China). The enzyme was used without any further purification.

\subsection{Transglutaminase treatment}

The caseins were dissolved in $100 \mathrm{~mL}$ distilled water at $5 \mathrm{mg} \cdot \mathrm{mL}^{-1}$ by constant mixing at $3000 \mathrm{rpm}\left(40{ }^{\circ} \mathrm{C}\right)$. Three samples of casein solution were prepared meanwhile. The $\mathrm{pH}$ of the solutions was kept at 7.0 with $1 \mathrm{M} \mathrm{NaOH}$. After caseins were completely dissolved, they were mixed with mTGase (which was pre-incubated at $37{ }^{\circ} \mathrm{C}$ with $30 \mathrm{~min}$ ) at the ratio of $15 \mathrm{U}^{-g^{-1}}$ caseins. The mixtures were incubated at $40{ }^{\circ} \mathrm{C}$ for $135 \mathrm{~min}$. The TGase reaction was inactivated by heating the sample at $85^{\circ} \mathrm{C}$ for $5 \mathrm{~min}$, followed by rapid cooling to room temperature in cold running water within $3 \mathrm{~min}$. The treated samples were acidified to $\mathrm{pH} 4-5$ with $1 \mathrm{M} \mathrm{HCl}$ and then centrifuged (TDD5M, Changsha Pingfan Instrument Co., Ltd., Changsha, China) at $4000 \times \mathrm{g}$ for $10 \mathrm{~min}$ at $20{ }^{\circ} \mathrm{C}$. The pellet was freeze-dried to constant weight. Then three batches of crosslinked caseins were achieved which were used to determine the extent of crosslinking individually and mixed together to measure the other properties.

\subsection{The modification degree of amino groups}

The modification degree of amino groups was determined by the $o$-phthalaldehyde (OPA) method (Yang et al. 2014a). In this experiment, $3 \mathrm{~mL}$ of caseins solution $\left(0.2 \mathrm{mg} \cdot \mathrm{mL}^{-1}\right)$ was mixed with $3 \mathrm{~mL}$ of OPA, which was prepared according to the method reported by Dinnella et al. (2002). After 2 min, absorbance was measured at $340 \mathrm{~nm}$ in a 1-cm length quartz cell (UV-2100 spectrophotometer; Beijing Beifen-Ruili Analytical Instrument Co., Ltd., Beijing, China). The number of amino groups was calculated from an L-leucine standard curve. The percentage of amino group-modified caseins was calculated using the following formula:

$$
\text { Modification degree }(\%)=\left(N_{\mathrm{o}}-N_{\mathrm{m}}\right) / N_{\mathrm{o}} \times 100
$$

where $N_{0}$ and $N_{\mathrm{m}}$ are the number of free amino groups in the unmodified and modified caseins, respectively.

\subsection{Solubility}

Caseins solubility was measured according to the method reported by Lawal and Adebowale (2004). Briefly, $1 \mathrm{~g}$ of caseins was dispersed in $100 \mathrm{~mL}$ of distilled water; $2.5 \mathrm{~mL}$ of the solution was mixed with distilled water and adjusted to $\mathrm{pH} 2-12 \mathrm{using}$ either $\mathrm{NaOH}$ or $\mathrm{HCl}$ solutions $(0.5-2.0 \mathrm{M})$. The final volume was $50 \mathrm{~mL}$. The mixtures were mixed by a vortex shaker (QL-866, Qilinbeier instrument manufacturing Co., 
Ltd., Jiangsu, China) at $3000 \mathrm{rpm}$ for $1 \mathrm{~min}$ every $10 \mathrm{~min}$ for $2 \mathrm{~h}$ and centrifuged at $10,000 \times g$ for $35 \mathrm{~min}$. Protein content in the supernatant was determined by the Kjeldahl method. Triplicate measurements were performed. Solubility was calculated using the following formula:

Solubility $\%=($ Amount of protein in the supernatant/Amount of protein in the sample $) \times 100$

\subsection{Emulsifying properties}

Caseins emulsifying properties were measured by the method reported by Pearce and Kinsella (1978) with slight modifications. To prepare the emulsions, $2.0 \mathrm{~mL}$ of canola oil and $6.0 \mathrm{~mL}$ of 2 g. $\mathrm{L}^{-1}$ caseins in water $(\mathrm{pH} 7.0)$ were mixed in a high-speed homogenizer (XHF-D, Ningbo Scientz Biological Technology Co., Ltd., Zhejiang, China) at 20,000 rpm for $1 \mathrm{~min}$. Subsequently, $50 \mu \mathrm{L}$ aliquots of the emulsion were removed $0.5 \mathrm{~cm}$ from the bottom of the tube and dispersed in $5 \mathrm{~mL}$ of $0.1 \%(w / v)$ SDS. Absorbance was measured at $500 \mathrm{~nm}$ against a $0.1 \%(w / v)$ SDS solution blank. The emulsion was left undisturbed for $30 \mathrm{~min}$. Subsequently, $50 \mu \mathrm{L}$ aliquots were removed $0.5 \mathrm{~cm}$ from the bottom of the tube and dispersed in $5 \mathrm{~mL}$ of $0.1 \%(w / v)$ SDS. The absorbance of the solution was measured at $500 \mathrm{~nm}$ as described above. The emulsifying activity index (EAI, $\mathrm{m}^{2} \cdot \mathrm{g}^{-1}$ ) and emulsion stability index (ESI, \%) were calculated by the following formulas:

$$
\begin{gathered}
\text { EAI }\left(\mathrm{m}^{2} / \mathrm{g}\right)=2 \times 2.303 \times \mathrm{A}_{0} \times \text { dilution } /\left[\mathrm{C} \times \varphi(1-\theta) \times 10^{3}\right] \\
\operatorname{ESI}(\%)=100 \times \mathrm{A}_{30} / \mathrm{A}_{0}
\end{gathered}
$$

where $\mathrm{C}$ is protein concentration ( $\mathrm{g} . \mathrm{L}^{-1}$ ) before emulsification, $\varphi$ is optical path $(0.01 \mathrm{~m}), \theta$ is the oil volume fraction $(v / v)$ of the emulsion $(\theta=0.25$ here $)$, dilution is $100, \mathrm{~A}_{0}$ represents the absorbance at time zero, and $\mathrm{A}_{30}$ represents the absorbance after $30 \mathrm{~min}$. EAI and ESI were measured in triplicate.

\subsection{Water and oil absorption capacities}

Water and oil absorption capacities of caseins samples were determined according to Matemu et al. (2011). Briefly, distilled water or oil was added to caseins and mixed by a vortex shaker (QL-866, Qilinbeier Instrument Manufacturing Co., Ltd., Jiangsu, China) at $3000 \mathrm{rpm}$ for $1 \mathrm{~min}$ every $10 \mathrm{~min}$ for $30 \mathrm{~min}$. The contents were allowed to stand at room temperature for $2 \mathrm{~h}$ and centrifuged at $3000 \times \mathrm{g}$ for $30 \mathrm{~min}$. Free water or oil was removed carefully. The amount of absorbed water or oil was determined by weight difference.

\subsection{Foaming properties}

Foaming activity and foam stability were assessed by the method reported by Jiang and Zhao (2011) and Motoi et al. (2004) with some modifications. In this experiment, 
$100 \mathrm{~mL}$ of caseins in distilled water $(1 \%, w / v ; \mathrm{pH} 7)$ was transferred to a $250-\mathrm{mL}$ cylindrical glass cup and stirred at 20,000 rpm for $1 \mathrm{~min}$ in a high-speed homogenizer. Foam volume was measured immediately after agitation and again after $30 \mathrm{~min}$ of setting. Foaming capacity was expressed in terms of the relative overrun; foam stability was expressed as the ratio between foam volume after $30 \mathrm{~min}$ and the initial foam volume $(0 \mathrm{~min})$. Foaming capacity and foam stability were calculated using the following formulas:

$$
\begin{aligned}
& \text { Foaming capacity }=\left(V_{0} / V_{\mathrm{a}}\right) * 100 \\
& \text { Foam stability }=\left(V_{30} / V_{0}\right) * 100
\end{aligned}
$$

where $V_{0}$ is the foam volume at $0 \mathrm{~min}, V_{30}$ is the foam volume at $30 \mathrm{~min}$, and $V_{\mathrm{a}}$ is the initial liquid volume before foaming.

\subsection{Instability in the presence of salts}

To study the influence of $\mathrm{Ca}^{2+}, \mathrm{Mg}^{2+}$, and $\mathrm{Na}^{+}$strength on the instability of caseins, the caseins solution were mixed with an equal volume of 0 to $2.4 \mathrm{~mol} . \mathrm{L}^{-1}$ to achieve final concentrations of ions at $0.2,0.4,0.6,0.8,1.0$, and 1.2 mol.L ${ }^{-1}$, caseins at 10 g.L $\mathrm{L}^{-1}, \mathrm{pH}$ at 7.0. The solution was mixed by vortex shaker at $3000 \mathrm{rpm}$ for $1 \mathrm{~min}$ every $10 \mathrm{~min}$ for $1 \mathrm{~h}$, then left overnight at $4{ }^{\circ} \mathrm{C}$. Subsequently, $20 \mathrm{~mL}$ samples were centrifuged at $40,000 \times \mathrm{g}$ in $50 \mathrm{~mL}$ tube for $35 \mathrm{~min}$ at $20{ }^{\circ} \mathrm{C}$. The supernatant was removed, and the firm pellet at the bottom was weighed. The instability of caseins was indicated by the proportion of precipitate, which was calculated using the following formula:

The proportion of precipitate $\%=$ (the weight of precipitate/the weight of solution

$$
\text { before centrifugation) } \times 100 \%
$$

\subsection{Statistical analyses}

All data were expressed as mean $\pm \mathrm{SD}$ (standard deviation) from at least three independent trials. The differences were assessed by one-way analysis of variance (ANOVA) and Duncan's multiple range tests. Statistical significance was set at $p<0.05$. PASW Statistics 18.0 software (SPSS Inc., Chicago, IL, US) and Origin 8.0 (OriginLab Corporation, Northampton, MA, US) were used to analyze the data.

\section{Results and discussion}

\subsection{Crosslinking degree}

The modification degree of amino groups in yak and cow caseins was $20.04 \pm 1.2$ and $25.15 \pm 0.5 \%$, respectively. The modification degree of amino groups in cow caseins

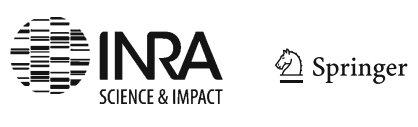


was higher than that of yak caseins, which revealed that the number and reactivity of amino groups and glutamine in yak and cow caseins differed, while different steric and conformational constraints affected the availability of amino groups for mTGase crosslinking (Jaros et al. 2006; Wang et al. 2013; Yang et al. 2014a). Ardelean et al. (2013) found that nearly $31 \%$ of the proteins in cow milk were crosslinked by the action of mTGase compared to only $9.6 \%$ of the proteins in goat milk. This indicates that the crosslinking extent of TGase depended on the milk source, which our results also show.

\subsection{Protein solubility}

The $\mathrm{pH}$-solubility profile of caseins and crosslinked caseins are shown in Fig. 1. The curve of the $\mathrm{pH}$-solubility profile had a minimum value at $\mathrm{pH} 4$ except for native yak caseins (at $\mathrm{pH} 4.5$ ). The solubility of crosslinked yak caseins was lower than the others in the $\mathrm{pH}$ ranges of 6-12 and 2-3, while the solubility of cow caseins was higher than the others. The solubility of crosslinked cow caseins was higher than that of native yak caseins in the $\mathrm{pH}$ range of 6-12 and at $\mathrm{pH} 2$. Compared to crosslinked caseins, native caseins had better solubility at all $\mathrm{pH}$ values except for $\mathrm{pH} 4.5$. In conclusion, mTGase treatment decreased casein solubility.

Yak caseins had lower solubility than cow caseins because of their larger particle diameter and higher mineral content (calcium, magnesium, and phosphorus), resulting in more mineral bonds and higher conformational stability than cow caseins (Wang et al. 2013; Li et al. 2011). Intra- and intermolecular crosslinks were formed via mTGase modification. Consequently, caseins underwent a conformational change, and high molecular weight insoluble biopolymers were formed (Partschefeld et al.

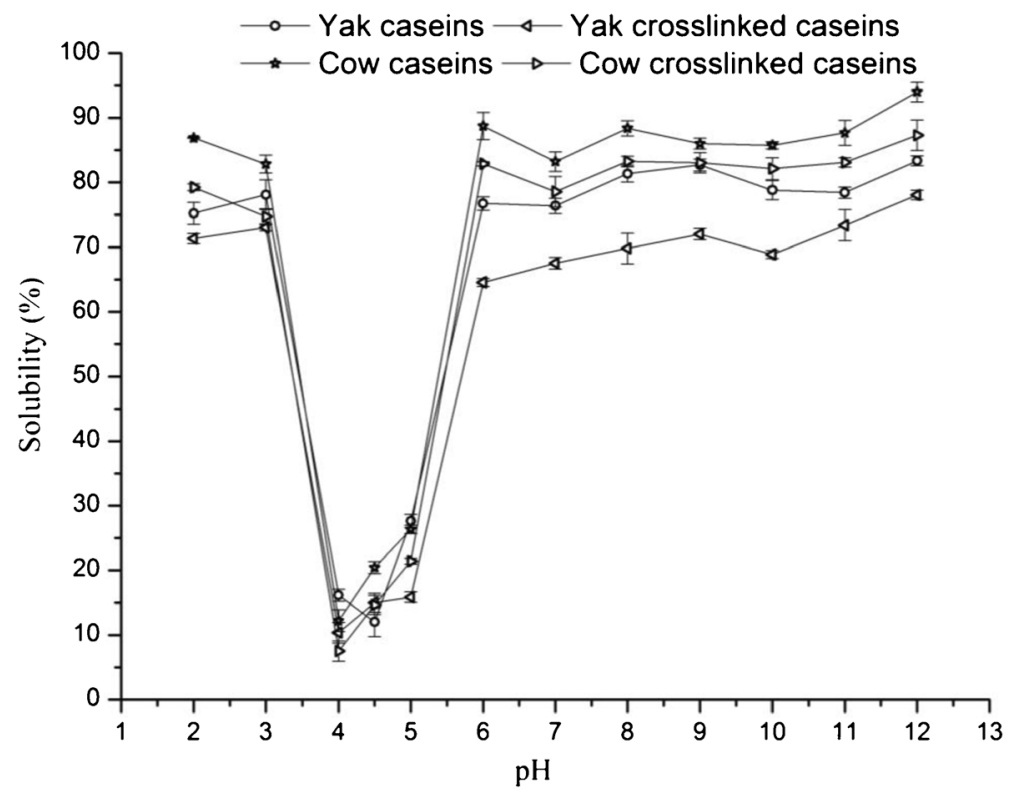

Fig. 1 Protein solubility profiles of yak and cow caseins. Values are means of data from experiments on three independent casein samples, with the standard deviation indicated by vertical error bars 
2007). As expected, mTGase treatment decreased solubility, especially at highly acidic $\mathrm{pH}(\mathrm{pH} 2)$ and $\mathrm{pH}$ above 6.0, which agrees with the results from kidney bean protein isolate (Tang et al. 2008). It also agrees with the results of pigeon pea and hyacinth bean protein isolates (Ali et al. 2010a, b). However, contrasting results were observed in mTGase-treated soy protein (Babiker 2000), where solubility at pH 2 and $\mathrm{pH} 8-12$ was greatly enhanced by mTGase treatment. The discrepancy may be due to differences in protein composition and conformation.

\subsection{Emulsifying properties}

The emulsifying activity of yak and cow caseins with and without crosslinking is shown in Fig. 2. The emulsifying activity decreased with increasing $\mathrm{pH}$ below the isoelectric point $(\mathrm{pH} 4)$ and increased above the isoelectric point. With mTGase treatment, the emulsifying activity of cow and yak caseins increased in all cases except at $\mathrm{pH} 4$ and 5. Cow caseins had lower emulsifying activity than yak caseins in all cases except for $\mathrm{pH} 7$.

Emulsification was influenced by protein solubility. As the protein became more soluble, a layer formed around the oil droplets to facilitate their association with the aqueous phase (Mirmoghtadaie et al. 2009). At pH 4-5, caseins had lower solubility resulting in lower emulsifying activity. Although the solubility of yak caseins was worse than that of cow caseins, their emulsifying activity was better, which is attributed to the good hydrophobic-hydrophilic balance in yak caseins. After crosslinking, the maximum emission wavelength of yak and cow caseins' intrinsic fluorescence shifted blue and the maximum fluorescence intensity increased (data not shown), which indicated that the hydrophobicity of yak and cow caseins increased. The increase in

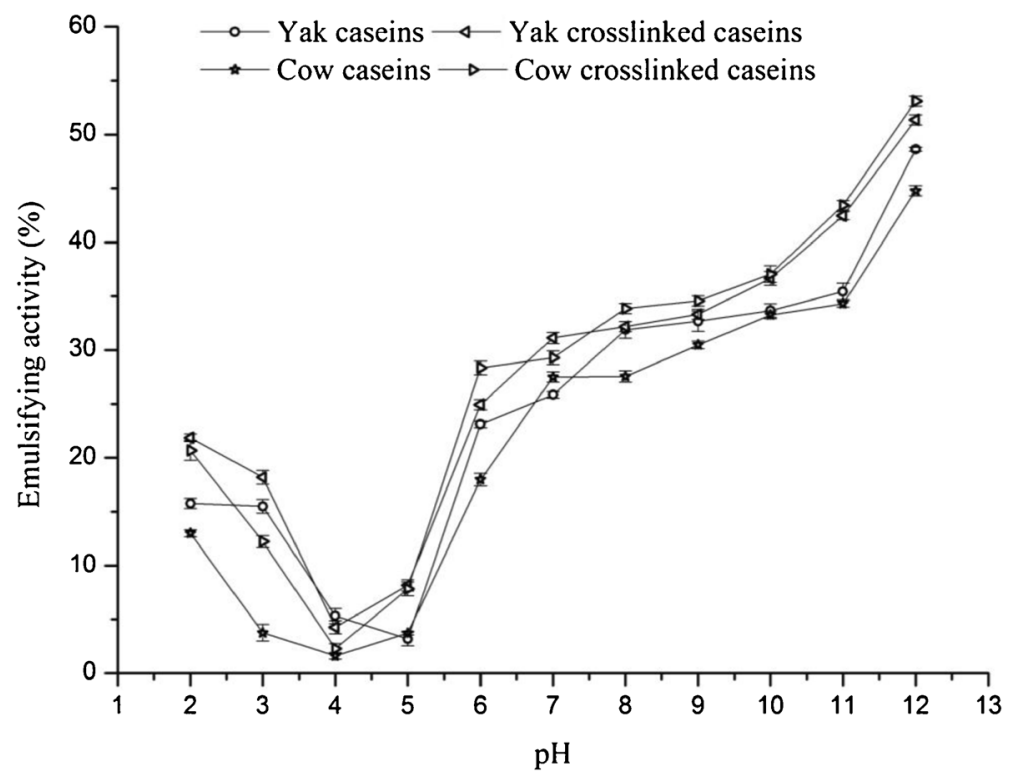

Fig. 2 Emulsifying activity of yak and cow caseins. Values are means of data from experiments on three independent casein samples, with the standard deviation indicated by vertical error bars 
emulsifying properties with modification was likely due to the improvement of the hydrophobic-hydrophilic balance.

The emulsion stability of yak and cow caseins is shown in Table 1. Yak caseins had high emulsion stability at $\mathrm{pH}$ above 8 and low emulsion stability at $\mathrm{pH}$ below 7 . The emulsion stability of cow caseins was poor except at $\mathrm{pH} 12$, but it was greatly improved at all $\mathrm{pH}$ levels except for $\mathrm{pH} 6$ after modification. MTGase modification improved the emulsion stability of yak caseins at all $\mathrm{pH}$ levels. In all cases, the emulsion stability of cow caseins was lower than that of yak caseins except at $\mathrm{pH} 3,6$, and 12.

Even though a decrease in solubility from crosslinking should decrease the emulsion stability of caseins, a change in conformation and an increase in the negative charge might improve the hydrophobic-hydrophilic balance, so that an elastic protein film could form at the oil-aqueous interface, and contribute to more stable emulsions (Yang et al. 2014a). Because of their good hydrophobic-hydrophilic balance, yak caseins had better emulsion stability than cow caseins. The results showed that polymerization of caseins was very effective in improving the emulsifying properties. Polymerization of caseins was shown to improve the emulsification properties of legume protein isolates (Ali et al. 2010a, b), which is in agreement with our results.

\subsection{Water and oil absorption capacity}

The water and oil absorption capacity of modified yak and cow caseins increased significantly after mTGase crosslinking (Fig. 3). Without modification, the water and oil absorption capacity of yak and cow caseins was not significantly different, but that of yak caseins was significantly higher after crosslinking.

The formation of intra- and intermolecular covalent bonds and the polymerization of caseins from crosslinking promoted the formation of the casein net structure and its ability to entrap water and oil. However, the extent of increase in the water and oil absorption capacity of yak caseins was higher than that of cow caseins, which indicated

Table 1 Emulsion stability of yak and cow caseins

\begin{tabular}{|c|c|c|c|c|}
\hline \multirow[t]{2}{*}{$\mathrm{pH}$} & \multicolumn{4}{|c|}{ Emulsion stability (\%) } \\
\hline & Yak caseins & Yak crosslinked caseins & Cow caseins & Cow crosslinked caseins \\
\hline 2 & $28.57 \pm 0.22^{\mathrm{aA}}$ & $32.74 \pm 0.14^{\mathrm{bA}}$ & $26.32 \pm 0.78^{\mathrm{c} \mathrm{A}}$ & $27.20 \pm 0.11^{\mathrm{d}} A$ \\
\hline 3 & $20.29 \pm 0.26^{\mathrm{aB}}$ & $27.97 \pm 0.45^{\mathrm{bB}}$ & $38.07 \pm 2.54^{\mathrm{cB}}$ & $48.24 \pm 0.34^{\mathrm{dB}}$ \\
\hline 6 & $15.54 \pm 0.21^{\mathrm{aC}}$ & $21.50 \pm 0.17^{\mathrm{bC}}$ & $19.32 \pm 0.31^{\mathrm{cC}}$ & $19.64 \pm 0.35^{\mathrm{cC}}$ \\
\hline 7 & $30.32 \pm 0.24^{\mathrm{aD}}$ & $63.21 \pm 0.15^{\mathrm{bD}}$ & $13.22 \pm 0.15^{\mathrm{cD}}$ & $24.33 \pm 0.23^{\mathrm{dD}}$ \\
\hline 8 & $55.32 \pm 0.42^{\mathrm{aE}}$ & $61.84 \pm 0.18^{\mathrm{bE}}$ & $13.60 \pm 0.28^{\mathrm{cD}}$ & $51.35 \pm 0.22^{\mathrm{dE}}$ \\
\hline 9 & $80.32 \pm 0.20^{\mathrm{aF}}$ & $80.36 \pm 0.25^{\mathrm{aF}}$ & $15.65 \pm 0.17^{\mathrm{bE}}$ & $54.38 \pm 0.21^{\mathrm{cF}}$ \\
\hline 10 & $79.60 \pm 0.20^{\mathrm{aG}}$ & $87.43 \pm 0.07^{\mathrm{bG}}$ & $15.18 \pm 0.15^{\mathrm{cE}}$ & $56.05 \pm 0.06^{\mathrm{dG}}$ \\
\hline 11 & $79.83 \pm 0.26^{\mathrm{aH}}$ & $79.91 \pm 0.22^{\mathrm{aH}}$ & $23.81 \pm 0.17^{\mathrm{bF}}$ & $61.21 \pm 0.07^{\mathrm{cH}}$ \\
\hline 12 & $75.35 \pm 0.14^{\mathrm{aH}}$ & $79.28 \pm 0.18^{\mathrm{bI}}$ & $91.40 \pm 0.05^{\mathrm{cG}}$ & $93.18 \pm 0.15^{\mathrm{dI}}$ \\
\hline
\end{tabular}

Values are mean \pm standard deviation; means with different superscript lowercase letters within the same row and capital letters within the same column are significantly different $(p<0.05)$ 


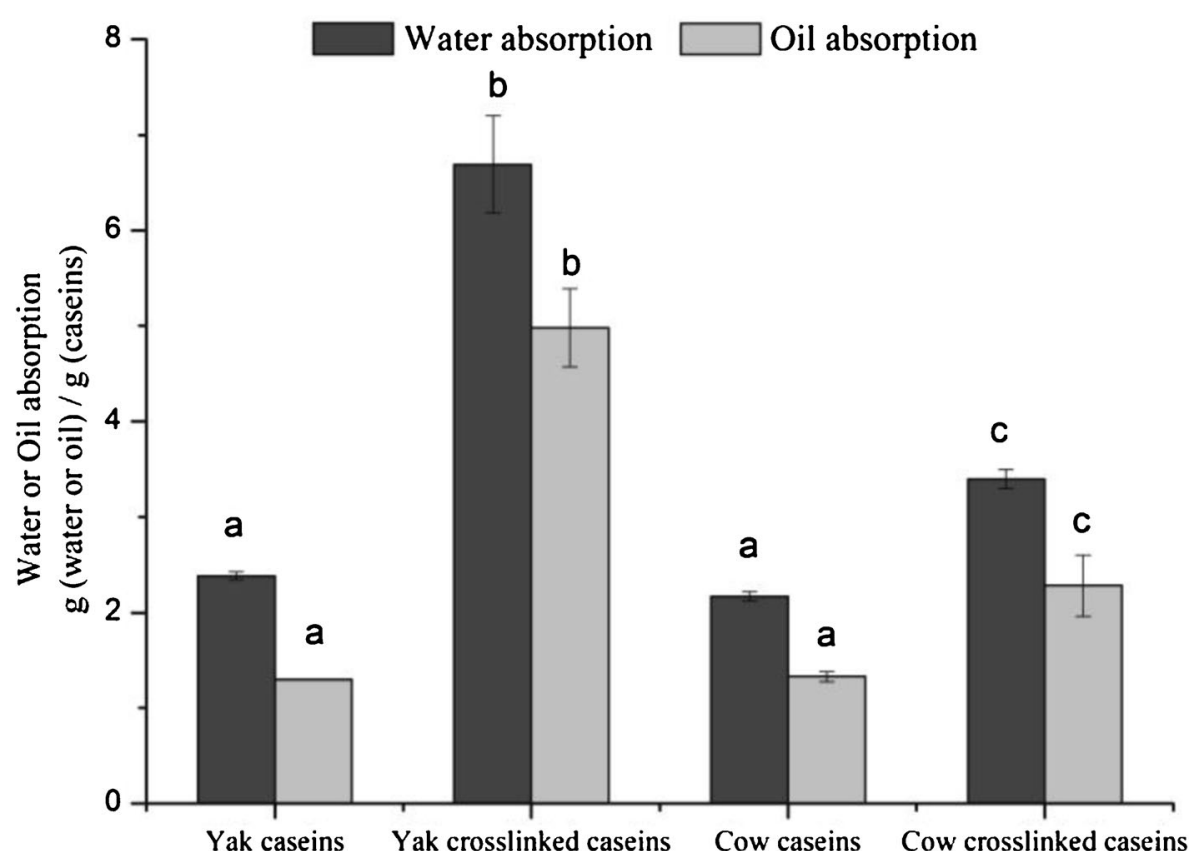

Fig. 3 Water or oil absorption capacity of yak and cow caseins. Values are means of data from experiments on three independent casein samples, with the standard deviation indicated by vertical error bars. Values of the same property with different letters are significantly different $(p<0.05)$

that the polymerization of yak caseins was very effective for improving the water and oil absorption properties.

\subsection{Foaming properties}

The effects of mTGase crosslinking on the foaming capacity of yak and cow caseins are shown in Fig. 4. The foaming capacity of yak caseins increased with mTGase modification. However, there was no significant difference between native cow caseins and crosslinked cow caseins. It has been reported that a good balance of hydrophilic and hydrophobic groups is necessary for foaming capacity and foam stability (Townsend and Nakai 1983). The increase in foaming capacity of caseins might be attributed to the change in surface hydrophobicity. After crosslinking, the foaming capacity of yak caseins was higher than that of cow caseins, which revealed that crosslinking contributes to a good balance of hydrophilic and hydrophobic groups in yak caseins.

The foam stability of modified caseins increased (Fig. 4) because a good hydrophilic-hydrophobic balance improved protein-protein interactions and promoted the formation of an elastic film at the air-liquid interface. Cow caseins had higher foam stability than yak caseins, which was attributed to their good solubility.

With mTGase treatment, the size of proteins increased and their crosslinked structure was more resistant to change than the native protein after high-speed homogenization, which is used to make emulsions and foams. The crosslinked protein easily formed an interfacial protein film, resulting in higher emulsifying and foaming properties. Cowpea, pigeon pea, and hyacinth bean protein isolates with mTGase crosslinking were 


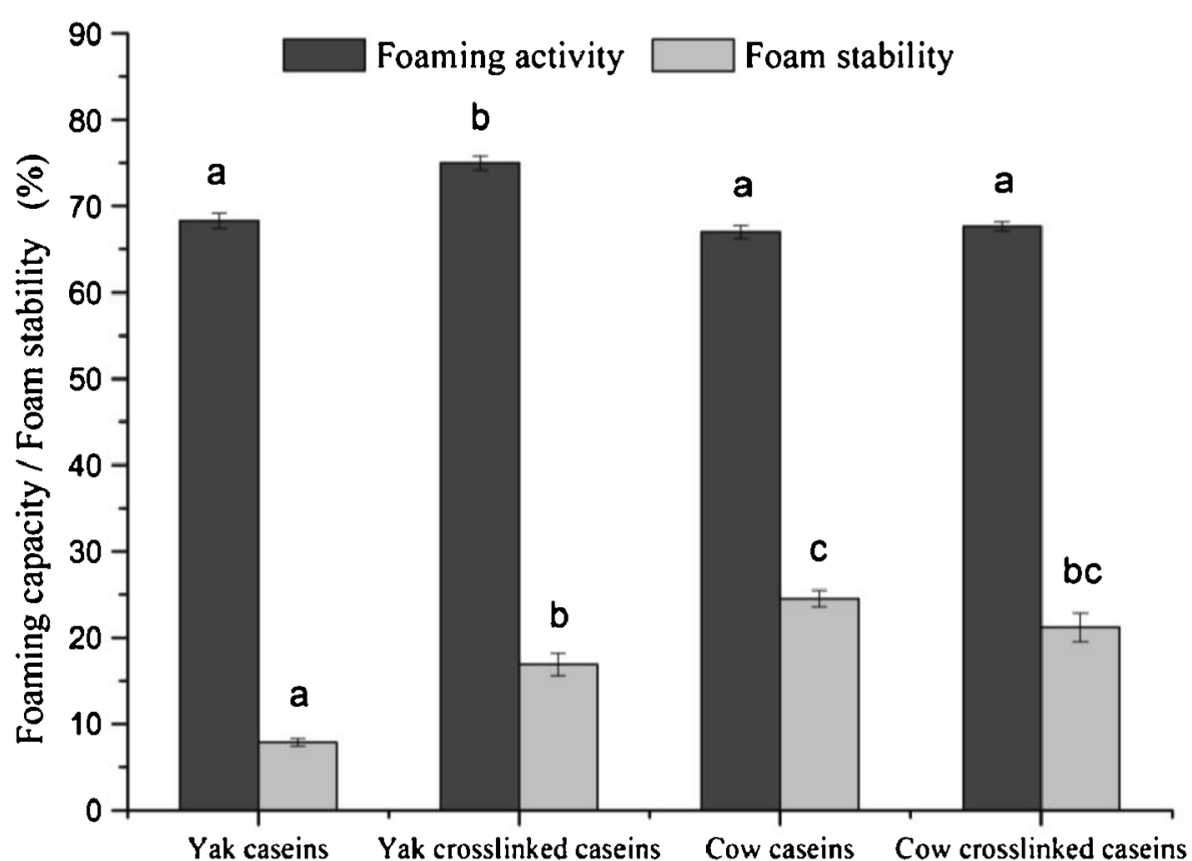

Fig. 4 Foaming capacity and foam stability of yak and cow caseins. Values are means of data from experiments on three independent casein samples, with the standard deviation indicated by vertical error bars. Values of the same property with different letters are significantly different $(p<0.05)$

also found to form better foam and have better emulsion forming ability than native isolates (Ali et al. 2010a, b; Aluko and Yada 1995).

\subsection{Instability of caseins in the presence of $\mathrm{CaCl}_{2}, \mathrm{MgCl}_{2}$, and $\mathrm{NaCl}$}

Changes in the instability of caseins with or without mTGase crosslinking as a function of $\mathrm{Ca}^{2+}, \mathrm{Mg}^{2+}$, and $\mathrm{Na}^{+}$concentration are outlined in Fig. 5. With mTGase treatment, the proportion of precipitate of yak and cow caseins decreased at all levels of ionic strength investigated $(0.2-1.2 \mathrm{M})$, indicating that the instability of caseins decreased. Increasing the concentration of $\mathrm{Ca}^{2+}, \mathrm{Mg}^{2+}$, and $\mathrm{Na}^{+}$increased the proportion of precipitate, which suggested a decrease in casein stability. The maximal proportion of precipitate was found with $\mathrm{Ca}^{2+}$, the minimal value was found with $\mathrm{Na}^{+}$at the same ionic strength, which revealed that caseins had good stability in the presence of $\mathrm{Na}^{+}$and poor stability in the presence of $\mathrm{Ca}^{2+}$. According to Fig. 5, cow caseins had better stability than yak caseins at all ionic strengths of $\mathrm{Ca}^{2+}, \mathrm{Mg}^{2+}$, and $\mathrm{Na}^{+}$.

The addition of salt causes positively charged ions to interact with the negatively charged proteins, thereby decreasing electrostatic repulsions and enhancing hydrophobic interactions. Caseins have a negative charge at $\mathrm{pH} \mathrm{7.0,} \mathrm{and} \mathrm{can} \mathrm{form}$ electrostatic interactions with the positively charged ions. Therefore, the proportion of precipitate with caseins in the presence of $\mathrm{Mg}^{2+}$ was higher than that for $\mathrm{Na}^{+} . \alpha-$ Casein and $\beta$-casein are calcium sensitive (Nagy et al. 2012), and are easily precipitated by $\mathrm{Ca}^{2+}$, resulting in a higher proportion of precipitate in $\mathrm{CaCl}_{2}$ than that in $\mathrm{MgCl}_{2}$. 
Fig. 5 Stability of yak and cow caseins in the presence of different $\mathrm{CaCl}_{2}, \mathrm{MgCl}_{2}$, and $\mathrm{NaCl}$ strength. Values are means of data from experiments on three independent casein samples, with the standard deviation indicated by vertical error bars
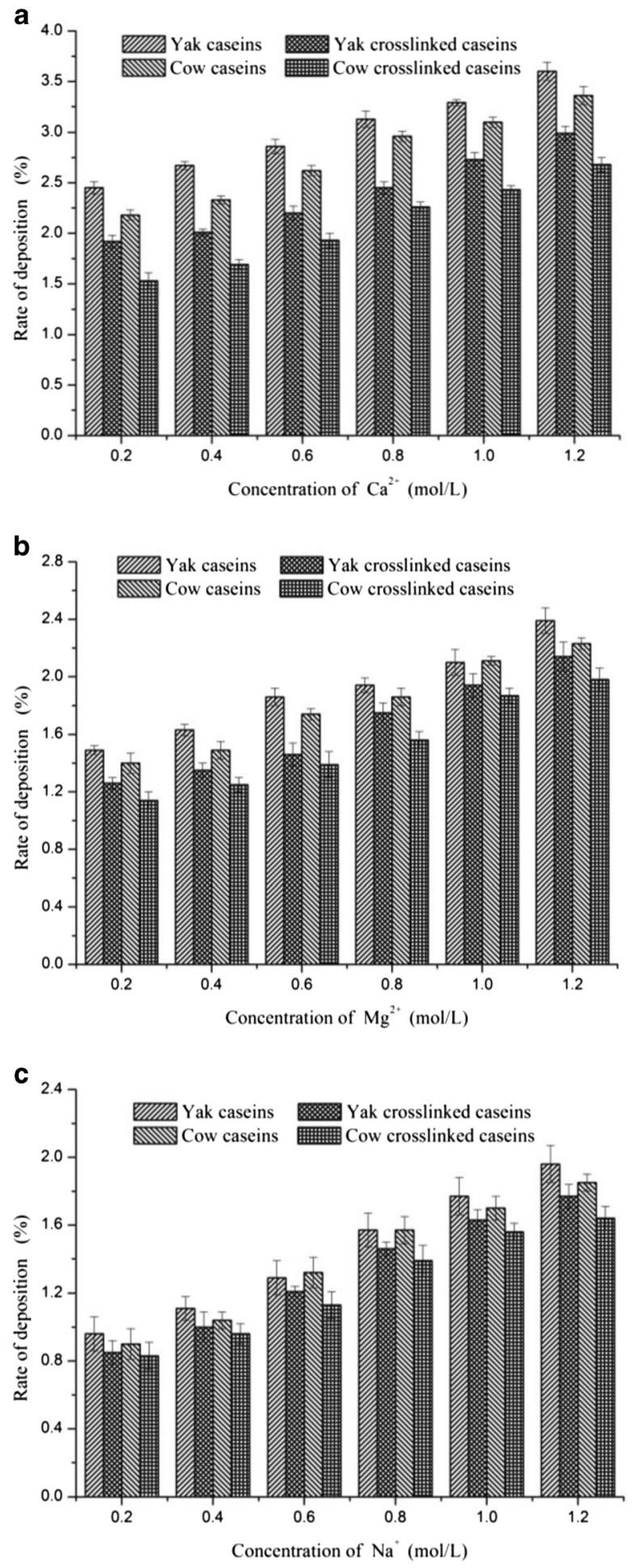

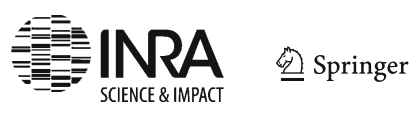


With an increase in the ionic strength of $\mathrm{Ca}^{2+}, \mathrm{Mg}^{2+}$, and $\mathrm{Na}^{+}$, the increase in hydrophobic interactions results in a higher tendency for the protein to form insoluble aggregates, thus increasing the proportion of precipitate (Aluko and Yada 1995). However, polymerization of the native protein by mTGase might increase the net negative charge on the protein, coupled with the salting-in effect of $\mathrm{CaCl}_{2}, \mathrm{MgCl}_{2}$, and $\mathrm{NaCl}$ on the hydrophobic interactions dissociating the caseins aggregates. This ultimately decreases the proportion of precipitate (Ali et al. 2010a, b). The results indicated that mTGase treatment was effective in improving the stability of caseins in the presence of $\mathrm{Ca}^{2+}, \mathrm{Mg}^{2+}$, and $\mathrm{Na}^{+}$compared to the native caseins.

\section{Conclusion}

Because of their different amino acid sequences and conformations, the functional properties of yak and cow caseins differ. Comparison of untreated caseins showed that yak caseins had lower solubility, foam stability and instability in the presence of $\mathrm{Ca}^{2+}$, $\mathrm{Mg}^{2+}$, and $\mathrm{Na}^{+}$, and higher emulsifying properties and foaming capacity than cow caseins. There was no significant difference in the water and oil absorption capacity between yak and cow caseins.

The modification degree of amino groups in yak and cow caseins differed at the same mTGase concentration, but the change in the trend of their functional properties was similar. After mTGase crosslinking, the solubility of caseins decreased, while the emulsifying properties increased because of casein polymerization. MTGase crosslinking was an effective method for improving the water and oil absorption properties of caseins, stability in the presence of $\mathrm{Ca}^{2+}, \mathrm{Mg}^{2+}$, and $\mathrm{Na}^{+}$, and foaming activity, which did not affect foam stability.

Acknowledgments This study was supported by the Postdoctoral Science Foundation of China (No. 2015M572611).

\section{References}

Ali NA, Ahmed SH, Mohamed EA, Ahmed IAM, Babiker EE (2010a) Changes in functional properties by transglutaminase cross linking as a function of $\mathrm{pH}$ of legumes protein isolate. Innov Rom Food Biotechnol 7(9):12-20

Ali NA, Ahmed SH, Mohamed EA, Ahmed IAM, Babiker EE (2010b) Effect of transglutaminase cross linking on the functional properties as a function of $\mathrm{NaCl}$ concentration of legumes protein isolate. World Acad Sci Eng Technol 37:1074-1079

Aluko RE, Yada RY (1995) Some functional properties of a cowpea (Vigna unguiculata) globulin isolate treated with transglutaminase. Biosci Biotechnol Biochem 59(12):2298-2299

Ardelean AI, Jaros D, Rohm H (2013) Influence of microbial transglutaminase cross-linking on gelation kinetics and texture of acid gels made from whole goats and cows milk. Dairy Sci Technol 93(1):63-71

Babiker EE (2000) Effect of transglutaminase treatment on the functional properties of native and chymotrypsin-digested soy protein. Food Chem 70(2):139-145

Dinnella C, Gargaro MT, Rossano R, Monteleone, E (2002) Spectrophotometric assay using o-phtaldialdehyde for the determination of transglutaminase activity on casein. Food Chem 78(3):363-368

Flanagan J, Gunning Y, FitzGerald RJ (2003) Effect of cross-linking with transglutaminase on the heat stability and some functional characteristics of sodium caseinate. Food Res Int 36(2):267-274 
Huppertz T, de Kruif CG (2007) Ethanol stability of casein micelles cross-linked with transglutaminase. Int Dairy J 17(5):436-441

Jaros D, Partschefeld C, Henle T, Rohm H (2006) Transglutaminase in dairy products chemistry physics applications. J Texture Stud 37(2):113-155

Jiang SJ, Zhao XH (2011) Transglutaminase-induced cross-linking and glucosamine conjugation of casein and some functional properties of the modified product. Int Dairy J 21(4):198-205

Lawal OS, Adebowale KO (2004) Effect of acetylation and succinylation on solubility profile water absorption capacity oil absorption capacity and emulsifying properties of mucuna bean (Mucuna pruriens) protein concentrate. Food/Nahrung 48(2):129-136

Li HM, Ma Y, Dong AJ, Wang JQ, Li QM, He SH, Maubois JL (2010) Protein composition of yak milk. Dairy Sci Technol 90(1):111-117

Li HM, Li H, Ma Y, Li Q, Wang J, Cheng J, Xue J, Shi J (2011) The chemical composition and nitrogen distribution of Chinese yak (maiwa) milk. Int J Mol Sci 12(8):4885-4895

Lorenzen PC (2000) Techno-functional properties of transglutaminase-treated milk proteins. Milchwissenschaft 55(12):667-670

Matemu AO, Kayahara H, Murasawa H, Katayama S, Nakamura S (2011) Improved emulsifying properties of soy proteins by acylation with saturated fatty acids. Food Chem 124(2):596-602

Mirmoghtadaie L, Kadivar M, Shahedi M (2009) Effects of succinylation and deamidation on functional properties of oat protein isolate. Food Chem 114(1):127-131

Motoi H, Fukudome S, Urabe I (2004) Continuous production of wheat gluten peptide with foaming properties using immobilized enzymes. Eur Food Res Technol 219(5):522-528

Nagy K, Váró G, Szalontai B (2012) K-casein terminates casein micelle build-up by its "soft" secondary structure. Eur Biophys J 41(11):959-968

Partschefeld C, Schwarzenbolz U, Richter S, Henle T (2007) Crosslinking of casein by microbial transglutaminase and its resulting influence on the stability of micelle structure. Biotechnol J 2(4):456461

Pearce KN, Kinsella JE (1978) Emulsifying properties of proteins: evaluation of a turbidimetric technique. J Agric Food Chem 26(3):716-723

Schorsch C, Carrie H, Clark AH, Norton IT (2000a) Cross-linking casein micelles by a microbial transglutaminase conditions for formation of transglutaminase-induced gels. Int Dairy J 10(8):519-528

Schorsch C, Carrie H, Norton IT (2000b) Cross linking casein micelles by a microbial transglutaminase influence of cross links in acid induced gelation. Int Dairy J 10(8):529-539

Smiddy MA, Martin JE, Kelly AL, de Kruif CG, Huppertz T (2006) Stability of casein micelles cross-linked by transglutaminase. J Dairy Sci 89(6):1906-1914

Tang CH, Sun X, Yin SW, Ma CY (2008) Transglutaminase-induced cross-linking of vicilin-rich kidney protein isolate: influence on the functional properties and in vitro digestibility. Food Res Int 41(10):941947

Townsend AA, Nakai S (1983) Relationships between hydrophobicity and foaming characteristics of food proteins. J Food Sci 48(2):588-594

Vasbinder AJ, Rollema HS, Bot A, de Kruif CG (2003) Gelation mechanism of milk as influenced by temperature and $\mathrm{pH}$; studied by the use of transglutaminase cross-linked casein micelles. J Dairy Sci 86(5):1556-1563

Wang P, Liu H, Wen P, Zhang H, Guo H, Ren F (2013) The composition size and hydration of yak casein micelles. Int Dairy J 31(2):107-110

Yang M, Shi Y, Wang P, Liu H, Wen P, Ren F (2014a) Effect of succinylation on the functional properties of yak caseins a comparison with cow caseins. Dairy Sci Technol 94(4):359-372

Yang M, Zhang W, Wen P, Zhang Y, Liang Q (2014b) Heat stability of yak micellar casein as affected by heat treatment temperature and duration. Dairy Sci Technol 94(5):469-481 